\title{
Грузия снова в тени Путина
}

\author{
Кристофер Роско *
}

\section{Введение}

Продолжая свою работу, направленную на экономическую модернизацию страны и ее принятие в Организацию Североатлантического договора (НАТО) и Европейский союз (ЕС), правительство Грузии должно сначала нормализовать отношения с Российской Федерацией для того, чтобы облегчить достижение этих долгосрочных целей. Грузия должна взвесить преимущества терпеливой политики неприсоединения в краткосрочном и среднесрочном плане и агрессивной политики немедленной интеграции с Западом. Наиболее эффективным путем для Грузии было бы улучшать условия существования своих граждан, одновременно обеспечивая физическую безопасность на своих границах, которые сейчас являются зонами повышенного напряжения. Враждебность между правительствами России и Грузии невыгодна обеим странам, и в большей степени грузинскому населению. Грузия выиграет больше от восстановления отношений и следовательно, она должна начать диалог, не выставляя предварительным условием для начала переговоров выход России из Южной Осетии и Абхазии.

Рекомендации, выдвинутые в этой работе, возможно, для многих граждан Грузии будут выглядеть как надругательство, и особенно для людей из грузинской политической сферы. События, которые произошли, и жертвы, принесенные в Абхазии и Южной Осетии, по-настоящему могут быть оценены только людьми, которые были напрямую причастны к ним. Неприязнь к России среди населения Грузии понятна. Большинство суверенных государств не любят советов, касающихся их внутренних дел, со стороны иностранцев, но Грузия должна признать существование перечисленных ниже факторов, связанные с ситуацией в сфере безопасности, и должна их учитывать, даже если предпочтет не принимать никаких действий.

Возможно, наиболее значимыми фактами, которые следует принять к сведению, являются:

- Владимир Путин был избран Президентом России;

\footnotetext{
Полковник Кристофер Роско на настоящий момент является командиром 405-й бригады полевой поддержки Сухопутных войск США, расположенной в Германии. Во время его стипендианства в Центре им. Джорджа К. Маршалла его исследования были направлены на широкий спектр проблем, стоящих перед Кавказским регионом, и конкретно на вопросы безопасности Грузии и внешнюю политику России. В течении всей своей военной карьеры полковник Роско более 15 лет занимал различные должности за границей, в основном в Европе и на Ближнем Востоке, в том числе и должность начальника отдела военной разведки в Объединенном командовании НАТО в Неаполе, Италия. Он имеет степень бакалавра по микробиологии Университета Техаса и степень магистра бизнесадминистрации Университета Иллинойса в Чикаго.
} 
- Иран становится более нестабильным;

- Ни одно государство не дало Грузии гарантии безопасности;

- $\quad$ ЕС и Турция слишком зависимы от России в области энергоносителей, и как по экономическим, так и по политическим соображениям не желают оказывать слишком сильное давление на своего торгового партнера.

Что касается надежд Грузии на помощь со стороны Соединенных Штатов, то США не имеют желания агрессивно противоборствовать России по проблеме Грузии. В частности, наиболее значимым результатом встречи между президентом США Бараком Обамой и Президентом Грузии Михаилом Саакашвили в Белом доме 31 января 2012 была заявленная готовность изучить возможность заключения соглашения о свободной торговле между двумя государствами. Подобная готовность была заявлена и три года назад в Хартии о стратегическом партнерстве Соединенных Штатов и Грузии, обнародованной 9 января 2009 года. В итоге этого визита США не взяли на себя никаких гарантий обеспечения безопасности Грузии. Соединенные Штаты не желают противоборствовать России и по другим причинам. Россия нужна США также для обеспечения доставки астронавтов и грузов на Международную космическую станцию. Вашингтон имеет свои экономические интересы в отношениях с Россией, проистекающие из факта вступления России во Всемирную торговую организацию, в том числе и отмена поправки Джексона-Вэника. Вдобавок к попыткам «перезагрузить» отношения США-Россия, у США свои финансовые проблемы, к тому же фокус военных интересов смещается в некоторой мере с Европы на регион Тихого океана. США испытывают большое уважение к Грузии и ее руководству, но у них значительно более обширные стратегические интересы, которые нужно принимать во внимание. Обращая внимание на эти факторы (и на некоторые другие, которые здесь не обсуждаются), Грузия должна признать необходимость предпринятия определенных шагов для ослабления напряжения в отношениях с Россией, если сама Грузия надеется создать атмосферу безопасности и оживленной экономической активности.

\section{Что Грузия может сделать?}

У Грузии есть несколько непосредственных, простых и недорогих вариантов действий, которые могли бы способствовать разрядке напряжения с Россией. Эти усилия не повредили бы суверенитету Грузии и могли бы действительно улучшить отношения Грузии с западными правительствами, поскольку любое действие, направленное на устранение трений на Кавказе, воспринимается благосклонно политиками США и ЕС. Варианты действий, которые можно было бы рассмотреть, включают:

- Не утрировать роль Северного Кавказа в политике Грузии;

- Демонстрировать позитивное отношение к Олимпийским играм 2014 в Сочи; 
- Смягчить обеспокоенность России насчет возможности расширения НАTO;

- Снизить уровень открытой антирусской риторики в публичных выступлениях, официальных документах и в действиях парламента;

- Понизить приоритет решения проблемы независимости Абхазии и Южной Осетии в национальной политике.

Грузии не нужно становиться сторонником России, но если она хочет реализовать полностью свой потенциал, ей необходимы работающие отношения с северным соседом.

\section{Стратегия по Северному Кавказу}

Администрация США обращала внимание на стратегию Грузии в отношении Северного Кавказа как на источник озабоченности и в 2011, и в 2012, когда генераллейтенант (в отставке) Джеймс Клаппер, Директор Национальной разведки, информировал Конгресс США о том, что политика Грузии в регионе нагнетает напряжение на Кавказе и увеличивает подозрительность России относительно намерений Грузии. Грузия, конечно, осознает чувствительность России к этому региону. Не далее как в 2010 году были обнародованы оценки, согласно которым на Северном Кавказе погибли не менее 1700 русских. Любые грузинские трансграничные действия, направление на изоляцию жителей Чечни, Дагестана, Балкарии и других регионов Кавказа от остальной России, такие как разрешение безвизовых поездок только для жителей Северного Кавказа, будут восприниматься как направленные на дестабилизацию России. Краткосрочные экономические выгоды, связанные с увеличением поездок, вряд ли перевесят стратегическую цену провалившейся дипломатии.

\section{Содействие Олимпийским играм 2014 в Сочи}

Широко известно, что Владимир Путин считает эффективную реализацию международных мероприятий на территории России ключевым элементом стратегии улучшения имиджа Российской Федерации в рамках мирового общественного мнения. Он заявил об этом в пространной, написанной лично им, статье, которая была опубликована РИА Новости 4 марта 2012, незадолго до президентских выборов в России. Есть несколько весьма заметных мероприятий, запланированных на следующие шесть лет президентства Путина, но из-за своей близости к Абхазии наибольшее внимание в Грузии привлекают Олимпийские игры в Сочи. Поддержав вначале заявку России на Зимние олимпийские игры в 2014, впоследствии Грузия систематически и публично начала утверждать, что Россия грабит ресурсы Абхазии, чтобы подготовить Сочи к играм. Хотя неожиданная защита Грузии абхазских экологических интересов похвальна, политизирование Олимпийских игр, вероятнее всего, вызовет ответный огонь. Противопоставление Грузии не заставит ни одно государство отказаться от участия в Играх, и обеспечит России аргументы для обвинений по отношению к Грузии в случае возникновения проблем с безопасностью во время Олимпиады. 


\section{Смягчение обеспокоенности России насчет возможности расширения HATO}

Путин рассмотрел вопросы, связанные с расширением НАТО и с планом противоракетной обороны США в упомянутой выше статье о внешней политике, опубликованной в конце его президентской кампании. Он отметил, что расширение НАТО подрывает безопасность России и глобальную стабильность. Грузии не следует навязывать вопрос о ее принятии в НАТО в повестку дня саммитов в ближайшем будущем. Вместо этого Грузии следует рассмотреть возможность выбора одной из двух линий поведения в отношении ее принятия в НАТО. Она или должна заявить, что пересматривает свои планы на принятие, или просто тихо отложить пока этот вопрос на несколько лет. В любом случае Грузия не отказывается от своего намерения в конечном итоге стать членом НАТО, но просто замедлит темп публичных шагов на пути к полноправному членству, шагов, которые вызывают беспокойство у России. Поскольку большинство аналитиков считают, что момент ее вступления в НАТО наступит гораздо позднее, чем того Грузии хотелось бы, нет никакого риска замедления выполнения курса на принятие в НАТО. Потенциально, когда-нибудь это случится. Но реальность такова, что грузинский процесс уже замедлился и это не так плохо, ни для НАТО, ни для Грузии. Уменьшение враждебности между Грузией и Россией имеет свои преимущества, и в то же время замедление темпа в конечном итоге не подвергает никакому риску сам факт принятия Грузии в НАТО.

\section{Ограничение антирусской риторики}

Рекомендация ограничить открытую антирусскую риторику в грузинских средствах массовой информации и в заявлениях ее руководства не требует от Грузии явным образом расхваливать Россию. Скорее, Грузии следует внимательно выбирать подходящие форумы, на которых обсуждаются ее обиды на гораздо более значительного соседа. Сейчас практически невозможно прочитать публичное выступление официальных грузинских лиц и не найти унизительное замечание или непрямой укол в сторону Москвы. Концепция национальной безопасности Грузии, принятая грузинским парламентом в декабре 2011, переперчена негативными ссылками на Российскую Федерацию. Парламент дошел до того, что в мае 2011 принял резолюцию о признании геноцида черкесов в Российской империи в 1800 году. Понятно, что никакой пользы официальное признание принести не может, кроме как только вызвать гнев России. Попытки Грузии унизить Россию в глазах международного сообщества сейчас вряд ли будут более эффективными, чем в прошлом, так что их следует ограничить.

\section{Смещение фокуса с Южной Осетии и Абхазии}

Последняя рекомендация, предлагаемая здесь, заключается в том, чтобы Грузия уменьшила упор на разрешение вопроса о независимости Южной Осетии и Абхазии. Очевидно, это будет самым трудным аспектом переориентировки, так как 
эмоциональные раны, связанные с этими конфликтами, еще не затянулись. Эти территориальные споры являются препятствием не только в отношениях с Россией, но и препятствием на пути принятия Грузии в НАТО и ЕС. Если Грузия сделает паузу в своей стратегии на получение членства, или вообще уступит в вопросе о полной независимости этих регионов, то это устранит пограничный спор и, возможно, откроет дорогу к более скорому принятию ее в НАТО или ЕС. Уступка этих территорий не означает, что они никогда не вернутся в состав Грузии. Но, что касается ближайшего будущего, эти территории не желают быть частью Грузии, и ни сила, ни дипломатия не могут решить данную проблему. После 1801 года и до сего дня, возможно, за исключением периода с 1918 года по 1921 год, Грузия никогда не контролировала в действительности эти области. На этих территориях проживают немногие (если вообще есть такие) этнические грузины и еще вопрос, пожелают ли они вернуться, если будет такая возможность. Грузии следует отдать больший приоритет связям с Россией, нежели русской деоккупации.

\section{Заключение}

Россия совершила много жестокостей против грузинской нации. Сотни тысяч жителей были выселены с начала 1990-х и тысячи людей с обеих сторон были убиты или ранены после распада Советского Союза. Несмотря на эти обиды, Грузия должна смотреть вперед, а не назад, и осознавать, что она все равно остается в тени Путина и Российской Федерации. Ее географическое положение требует такой дипломатической изощренности и умений, которые другим государствам никогда не понадобилось бы достигать. У Грузии нет международных гарантий безопасности, и она не подписывала никаких двухсторонних оборонительных соглашений. Хотя избрание Иванишвили на пост премьер-министра, возможно, и является шагом в правильном направлении, остается еще много работы. Правление Путина в качестве президента на следующие шесть или двенадцать лет, вероятно всего означает, что нежелательное статус-кво нестабильности в Тбилиси сохранится, если со стороны Грузии не будут предприняты положительные действия. Грузии следует действовать незамедлительно. После объявления независимости Грузия достигла серьезного прогресса и успехов, и они будут еще более значительными, если ей удастся идти по тонкой линии между связями с Россией и западными устремлениями. Имея в виду достигнутое, нам не следует сбрасывать со счетов ее шансы. 